Original article

\title{
Experimental evidence of indirect transmission of Mycoplasma synoviae
}

\author{
Corinne MAROIS ${ }^{\mathrm{a}}$, Jean-Paul PICAULT ${ }^{\mathrm{b}}$, Marylène KOBISCH ${ }^{\mathrm{a}}$, \\ Isabelle KEMPF ${ }^{a *}$ \\ a Agence Française de Sécurité Sanitaire des Aliments (AFSSA), Laboratoire d'Études et de Recherches \\ Avicoles et Porcines, Unité de Mycoplasmologie Bactériologie, BP 53, 22440 Ploufragan, France \\ b Agence Française de Sécurité Sanitaire des Aliments (AFSSA), Laboratoire d'Études et de Recherches \\ Avicoles et Porcines, Unité de Virologie Immunologie Parasitologie Aviaires et Cunicoles, BP 53, \\ 22440 Ploufragan, France
}

(Received 19 November 2004; accepted 2 March 2005)

\begin{abstract}
The aim of the study was to analyse experimental transmission of Mycoplasma synoviae, an avian pathogen. Three experiments using specific pathogen-free day-old chicks placed in isolators were conducted. In the first experiment, the birds were introduced in an isolator previously contaminated with a $M$. synoviae broth culture. After 34 days, these birds were eliminated and, for the second trial, the chicks were introduced in the same isolator without disinfecting. In the third assay, the chicks were placed in an isolator containing a mixture of food, feathers and dust collected less than an hour earlier from a M. synoviae infected laying hen flock. In the second and third experiments in order to exacerbate the $M$. synoviae infection, the birds were inoculated with infectious bronchitis (IB) virus. The presence of M. synoviae in the environment and in tracheal swabs was monitored by culture, a multiplex PCR (mPCR) detecting M. synoviae and Mycoplasma $16 \mathrm{~S}$ rDNA and a multiplex RT-PCR (mRT-PCR) detecting the $M$. synoviae mRNA coding for a membrane protein and Mycoplasma 16S rRNA. In in vitro experimental conditions, $M$. synoviae mRNA and 16S rRNA were detected up to $20 \mathrm{~min}$ and $23 \mathrm{~h}$ respectively after mycoplasma death. In the first assay, the first infected bird was detected on the 13th day. In the second trial, culturable $M$. synoviae or viable $M$. synoviae were detected in the isolator for 3 or 4 to 5 days respectively after depopulation of the birds of the first assay whereas the first culture positive tracheal swabs were detected on the 33rd day, after IB inoculation. In the third experiment, the first infected birds were detected on the 54th day. Thus, the different assays showed that $M$. synoviae contaminated material (dust, feathers and food) can infect chicks, sometimes after remarkably long silent periods.
\end{abstract}

\section{Mycoplasma synoviae / chicken / environment / transmission}

\section{INTRODUCTION}

Avian mycoplasmoses are frequently reported infectious diseases in poultry flocks. Mycoplasma synoviae is responsible for infectious synovitis and causes economic losses because of decreased egg production, growth and hatchability rates, and downgrading of carcasses at slaughter due to airsacculitis and arthritis lesions [12].

\footnotetext{
* Corresponding author: i.kempf@ploufragan.afssa.fr
} 
Transmission of mycoplasmas may be vertical, through the eggs, or horizontal either by direct contact between clinically affected or unaffected carriers and susceptible birds or by indirect contact via people, wild animals or maybe contaminated equipment. Such indirect transmission is rather unexpected for wall-less bacteria, which are supposed to be sensitive to osmotic shock, heating or chemical treatments. However, M. synoviae may persist on feathers up to 2 or 3 days at room temperature [3] and its high dissemination capacity has been demonstrated [16].

Three experimental studies were conducted in order to analyse $M$. synoviae horizontal transmission via a contaminated environment. In the second and third experiment, the $M$. synoviae infection was exacerbated by inoculation of birds with infectious bronchitis (IB) virus. In order to monitor the presence of dead or viable cells of $M$. synoviae in chicken tracheas and in their environment, a multiplex PCR (mPCR) and a multiplex RT-PCR (mRT-PC) were developed and their specificities and sensitivities were estimated. The delay of detection of the different targets (DNA, 16S rRNA or mRNA) after mycoplasma cell death was evaluated.

\section{MATERIALS AND METHODS}

\subsection{Bacterial strains and media}

A collection of 56 reference or field strains including $18 \mathrm{M}$. synoviae strains (the reference strain WVU 1853 and 17 field strains isolated from 1986 to 2000 from chickens or turkeys) and 38 species other than M. synoviae (Mollicutes species including 16 avian mycoplasma species, and non Mollicutes species) were used to test the PCR specificity (Tab. I).

For the first assay, the field strain $M$. synoviae 86122 isolated in 1986 from a chicken air sac strain was used. For determination of the detection period of mRNA and $16 \mathrm{~S}$
rRNA after mycoplasma death, the $M$. synoviae strain K1415, kindly given by S.H. Kleven (University of Georgia, USA) was used. The numbers of colony forming units (CFU) were determined according to Rodwell and Whitcomb [20].

M. synoviae was cultivated on FM4 media [6]. Transport Medium (TM) for mycoplasmas was $2 \%$ buffered peptone water (AES, Combourg, France) containing glycerine (Merck Eurolab, Briare Le Canal, France, $1.2 \% \mathrm{v} / \mathrm{v})$, bacterial growth inhibitor (Penicillin G, Sigma-Aldrich, Saint-QuentinFallavier, France, 1000 units per $\mathrm{mL}$ of medium) and thallium acetate (Merck Eurolab, $1.9 \mathrm{mM})$.

For the second and third assay, the infectious bronchitis (IB) virus Mass 41 strain [7] was used. The titre of the suspension was determined in embryonated chicken eggs according to the method of Reed and Muench [25].

\subsection{Experimental designs}

\subsubsection{Artificial contamination of the isolator}

In the first experiment, fifteen one-dayold specific pathogen free (SPF) chicks obtained from the experimental poultry unit of AFSSA-Ploufragan (France) were reared in one isolator. Prior to contamination, $15 \mathrm{~g}$ of food and $10 \mathrm{~mL}$ of drinking water were collected and one drag-swab (Sodibox, LaForêt-Fouesnant, France), previously humidified with $5 \mathrm{~mL}$ of TM was rubbed in the isolator. The food sample and the environmental drag swab were placed in $20 \mathrm{~mL}$ of TM before culture, mPCR and mRT-PCR and the drinking water sample was filtered and the membrane placed in FM4 medium was used for culture, mPCR and mRTPCR. Then, the environment of the isolator was contaminated by spreading $40 \mathrm{~mL}$ of a culture of the $M$. synoviae 86122 strain $\left(1.3 \times 10^{9} \mathrm{CFU} / \mathrm{m}^{3}\right)$ on the floor of the isolator. On days 13, 27 and 34 after the first assay started (D13, D27 and D34), tracheal 
Table I. Bacterial species used in the MPCR specificity test.

\begin{tabular}{|c|c|c|c|c|c|}
\hline \multirow{2}{*}{ Bacterial species } & \multirow{2}{*}{ Main host } & \multirow{2}{*}{ Source } & \multirow{2}{*}{$\begin{array}{c}\text { Number } \\
\text { tested }\end{array}$} & \multicolumn{2}{|c|}{ Multiplex PCR results } \\
\hline & & & & M. synoviae & Mollicutes \\
\hline \multirow[t]{2}{*}{ M. synoviae } & Poultry & $R^{a}-W V U 1853^{b}$ & 1 & + & + \\
\hline & Poultry & Field strains & 17 & + & + \\
\hline M. gallisepticum & Poultry & R - ATCC19610 & 1 & - & + \\
\hline M. meleagridis & Poultry & R - ATCC25294 & 1 & - & + \\
\hline M. iowae & Poultry & R - ATCC 33552 & 1 & - & + \\
\hline M. lipofaciens & Poultry & R - ATCC35105 & 1 & - & + \\
\hline M. gallopavonis & Poultry & R - ATCC 33551 & 1 & - & + \\
\hline M. gallinarum & Poultry & R - ATCC19708 & 1 & - & + \\
\hline M. glycophilum & Poultry & R - ATCC 35277 & 1 & - & + \\
\hline M. gallinaceum & Poultry & R - ATCC 33550 & 1 & - & + \\
\hline M. columbinasale & Poultry & R - ATCC 33549 & 1 & - & + \\
\hline M. columborale & Poultry & R - ATCC29258 & 1 & - & + \\
\hline M. columbinum & Poultry & R - ATCC29257 & 1 & - & + \\
\hline M. iners & Poultry & R - ATCC15969 & 1 & - & + \\
\hline M. anseris & Poultry & R - ATCC49234 & 1 & - & + \\
\hline M. anatis & Poultry & R - ATCC25524 & 1 & - & + \\
\hline M. cloacale & Poultry & R - ATCC 35276 & 1 & - & + \\
\hline M. pullorum & Poultry & R - ATCC 33553 & 1 & - & + \\
\hline M. hyopneumoniae & Pig & R - ATCC25934 & 1 & - & + \\
\hline M. flocculare & Pig & R - ATCC27399 & 1 & - & + \\
\hline M. hyorhinis & Pig & R - ATCC17981 & 1 & - & + \\
\hline M. hyosynoviae & Pig & R - ATCC25591 & 1 & - & + \\
\hline M. bovis & Bovine & R - ATCC25523 & 1 & - & + \\
\hline M. arginini & Cattle & R - ATCC23838 & 1 & - & + \\
\hline M. orale & Human & R - ATCC23714 & 1 & - & + \\
\hline M. pneumoniae & Human & R - ATCC15531 & 1 & - & + \\
\hline Acholeplasma laidlawii & Various & R - ATCC23206 & 1 & - & + \\
\hline Acholeplasma axanthum & Various & R - ATCC25176 & 1 & - & + \\
\hline Spiroplasma citri & Plant & R - ATCC27556 & 1 & - & + \\
\hline Ureaplasma urealyticum & Human & R - ATCC27618 & 1 & - & - \\
\hline Campylobacter coli & Various & Field strain & 1 & - & - \\
\hline Mannheimia haemolytica & Various & Field strain & 1 & - & - \\
\hline Haemophilus paragallinarum & Poultry & R - ATCC29545 & 1 & - & - \\
\hline Streptococcus suis & Pig & R - ATCC43765 & 1 & - & - \\
\hline Pasteurella multocida & Various & Field strain & 1 & - & - \\
\hline Actinobacillus & Pig & R - ATCC27088 & 1 & - & - \\
\hline Clostridium innосиит & Various & R - ATCC14501 & 1 & - & - \\
\hline Clostridium ramosum & Various & R - ATCC25582 & 1 & - & - \\
\hline Escherichia coli & Various & R - ATCC25902 & 1 & - & - \\
\hline Salmonella typhi & Various & R - ATCC167 & 1 & - & - \\
\hline
\end{tabular}

${ }^{a} \mathrm{R}$ : Reference strain.

b ATCC: American Type Culture Collection, Rockville, USA. 
swabs were collected from all chicks, placed in $2 \mathrm{~mL}$ of TM and analysed by culture and mPCR. The birds were sacrificed on D34.

\subsubsection{Contamination of the isolator with experimentally infected chickens}

In the second experiment, fourteen oneday-old SPF chicks were put in the isolator that had previously contained during 34 days the 15 chickens of the first experiment. The birds were introduced less than five minutes after depopulation of $M$. synoviae infected (see below) chickens. On day 21 (D21), they were inoculated intranasally with Infectious Bronchitis virus Mass 41 strain $\left(10^{3}\right.$ Embryo Infectious Doses $\left(\mathrm{EID}_{50}\right)$ per bird). Tracheal swabs collected on days D12, D18 and D27 from all chicks were analysed by mycoplasma culture and mPCR. On day D33, the chickens were sacrificed and autopsied. Tracheas and air sac samples were analysed by culture and mPCR.

In order to monitor $M$. synoviae in the isolator environment, for the first seven days following the elimination of the chickens of the first assay, three food samples, three feather samples, three water samples and one drag-swab previously rubbed in the isolator were analysed by culture, $\mathrm{mPCR}$ and mRT-PCR. M. synoviae cells were cultivated from environmental samples as previously described [16].

\subsubsection{Contamination of the isolator with naturally contaminated dust, feathers and food}

In the third experiment, another isolator was contaminated by scattering $672 \mathrm{~g} / \mathrm{m}^{3}$ of a mixture of dust, feathers and food that had been collected less than an hour earlier from a $M$. synoviae infected commercial laying hen flock (previous culture and PCR analysis of twenty tracheal swabs and serological tests had revealed that all analysed hens from the flock harboured M. synoviae and were serologically $M$. synoviae positive). Before contamination of the isolator, six samples of mixture of dust and feathers and three samples of food were collected for culture, mPCR and mRT-PCR in order to confirm the presence of $M$. synoviae. Then fifteen one-day-old SPF chicks were introduced into the isolator. Three hours later, the presence of darkling beetles was detected and Baycidal and Solfac products (Bayer, Puteaux, France) were used to kill the insects. On day 57 (D57), the chickens were inoculated intranasally with IB virus Mass 41 as previously described. Tracheal swabs were collected from all chicks on days D12, D26, D33, D40, D47, D54 and D63 and analysed by culture and mPCR. On day D69 the chickens were sacrificed and autopsied. Tracheas, spleens and air sac samples were analysed by culture or mPCR.

\section{3. mPCR: sample preparation and processing}

DNA extracts from environmental samples, tracheal swabs, tracheas and air sacs were prepared for PCR $[10,16]$.

The mPCR was developed to enable simultaneous detection of DNA of $M$. synoviae species and the genera Mycoplasma, Acholeplasma and Spiroplasma genera, which will be referred to as "Mollicutes" hereafter. A 422 base pair (bp) PCR product specific for $M$. synoviae was obtained with MSpcl5 and MSpcl4 primers (Tab. II) defined on the pcl42-56 gene coding for a membrane protein, described by ben Abdelmoumen et al. [2]. The second primer set (GPO3 and MGSO) based on 16S rDNA was used to detect most species of Mollicutes [23, 24] (but not Ureaplasma see below) with a better sensitivity than the species specific PCR. The mPCR mixture contained PCR buffer $(67 \mathrm{mM}$ Tris- $\mathrm{HCl}$, $16 \mathrm{mM} \quad\left(\mathrm{NH}_{4}\right)_{2} \mathrm{SO}_{4}, 0.01 \%$ Tween 20, $2.5 \mathrm{mM} \mathrm{MgCl}_{2}$ (pH 8.8)), a $600 \mu \mathrm{M}$ concentration of each deoxyribonucleoside triphosphate (dNTP) (Pharmacia Biotech, Orsay, France), $700 \mathrm{nM}$ of MSpcl5 and MSpcl4 primers, $150 \mathrm{nM}$ of GPO3 and MGSO primers (Oligo-express, Paris, France), 3 units of Taq DNA polymerase (Eurobio, 
Table II. Primers used to construct the PCR internal positive control and for mPCR.

\begin{tabular}{llc}
\hline Primer & \multicolumn{1}{c}{ Sequence } & $\begin{array}{c}\text { PCR product } \\
\text { (size) }\end{array}$ \\
\hline CI-5 & 5'-TCATTCAGCAGCGCCAGCTGGTTCCATGCATGTCGAGCGGAATTTAGC-3' & IPC \\
CI-6 & 5'-GCTTGAGTCTCCATTAACTTGTTGTATCTACGCATTCCACCGCTTCAC-3' & (645 bp) \\
MSpc15 & 5'-TCATTCAGCAGCGCCAGCTGGTTC-3' & M. synoviae \\
MSpc14 & 5'-GCTTGAGTCTCCATTAACTTGTTG-3' & (422 bp) \\
GPO3 & 5'-GGGAGCAAACAGGATTAGATACCCT-3' & $\begin{array}{c}\text { Mollicutes } \\
\text { (270 bp) }\end{array}$ \\
\hline MGSO & 5'-TGCACCATCTGTCACTCTGTTAACCTC-3' & \\
\hline
\end{tabular}

Les Ulis, France), $10 \mathrm{fg}$ of Internal Positive Control (IPC, see below) and $5 \mu \mathrm{L}$ of the DNA template. Amplification was performed in a Perkin-Elmer Cetus GeneAmp PCR system 9600 (Perkin Elmer, Courtaboeuf, France). The reaction procedure consisted of 40 cycles of denaturation at $94{ }^{\circ} \mathrm{C}$ for $30 \mathrm{~s}$, primer annealing at $65^{\circ} \mathrm{C}$ for $30 \mathrm{~s}$, and extension at $72{ }^{\circ} \mathrm{C}$ for $12 \mathrm{~s}$.

The amplified products were separated in a $2 \%$ agarose gel in TBE buffer $(90 \mathrm{mM}$ Tris, $90 \mathrm{mM}$ borate, $2.5 \mathrm{mM}$ EDTA (pH 8)) for $1 \mathrm{~h}$ at a constant voltage of $110 \mathrm{~V}$. Amplified products were detected by UV transillumination with ethidium bromide staining. A Smart Ladder (Eurogentec, Angers, France) was used as a molecular size standard.

\section{4. mRT-PCR: sample preparation and processing}

The mRT-PCR allowed detection in the environment of viable or recently dead cells belonging to the M. synoviae species or to the Mollicutes genera. Extraction of total RNA from $900 \mu \mathrm{L}$ of initial suspension of environmental samples was as previously described [17]. The RNA extracts were kept at $4{ }^{\circ} \mathrm{C}$ and controlled by PCR to confirm the absence of DNA.

The 16S rRNA fragment of Mycoplasma, Acholeplasma or Spiroplasma genera was reverse transcribed into cDNA with the MGSO primer and the $M$. synoviae specific mRNA fragment was reverse transcribed with the MSpcl4 primer. The Reverse Transcription (RT) mixture contained buffer (67 mM Tris-HCl, $16.6 \mathrm{mM}$ $\left.\left(\mathrm{NH}_{4}\right)_{2} \mathrm{SO}_{4}, 1 \mathrm{mM} \mathrm{MnCl}_{2}, \mathrm{pH} 8.8\right), 600 \mu \mathrm{M}$ concentration of each deoxyribonucleoside triphosphate (Pharmacia Biotech), $750 \mathrm{nM}$ of MGSO primer, $3150 \mathrm{nM}$ of MSpcl4 primer (Oligo-express), 15 units of Tth DNA polymerase (Eurobio), and $10 \mu \mathrm{L}$ of the RNA template in a total volume of $20 \mu \mathrm{L}$, under a drop of mineral oil. RT was performed at $65^{\circ} \mathrm{C}$ for $15 \mathrm{~min}$. Then microtubes were placed in ice. The whole RT mixture was mixed with PCR mixture containing buffer $(67 \mathrm{mM}$ Tris- $\mathrm{HCl}, 16.6 \mathrm{mM}$ $\left(\mathrm{NH}_{4}\right)_{2} \mathrm{SO}_{4}, 0.75 \mathrm{mM}$ EGTA, $5 \%$ glycerol, $0.02 \%$ Tween 20, $2.5 \mathrm{mM} \mathrm{MgCl}_{2}, \mathrm{pH} 8.8$ ), $150 \mathrm{nM}$ of GPO3 primer, $700 \mathrm{nM}$ of MSpcl5 primer and $1 \mathrm{fg}$ of IPC in a total volume of 100 $\mu \mathrm{L}$. Amplification was performed in a Perkin-Elmer Cetus GeneAmp PCR system 9600 (Perkin Elmer). The reaction procedure consisted of 40 cycles of denaturation at $94{ }^{\circ} \mathrm{C}$ for $30 \mathrm{~s}$, primer annealing at $65^{\circ} \mathrm{C}$ for $30 \mathrm{~s}$, and extension at $72{ }^{\circ} \mathrm{C}$ for $12 \mathrm{~s}$.

The amplified products were separated by electrophoresis as previously described. In the results section, a positive mPCR result means that both $M$. synoviae and Mollicute specific fragments were amplified. 


\subsection{Sensitivity of the MPCR and RT- PCR tests}

The sensitivities of the MPCR and mRTPCR methods were evaluated using ten fold dilutions of titrated $M$. synoviae cultures in exponential growth phase.

\subsection{Detection of $\mathrm{mRNA}$ and $16 \mathrm{~S}$ rRNA after mycoplasma death}

The detection period of mRNA and $16 \mathrm{~S}$ rRNA after mycoplasma death was evaluated after death due to osmotic shock of $M$. synoviae strain K1415. One millilitre of $M$. synoviae culture containing $6.6 \times 10^{6} \mathrm{CFU}$ was mixed with $99 \mathrm{~mL}$ of TE buffer $(10 \mathrm{mM}$ Tris-HCl, 1mM EDTA ( $\mathrm{pH} 8.0)$ ). A control of the non cultivability of the suspension was performed by inoculating this suspension in FM4 agar or liquid media. The dead mycoplasma suspension was placed at room temperature. Immediately after osmotic shock and 1, 2, 3, 4, 5, 6, 7, 9, 10, $12,14,16,18,20,25,30 \mathrm{~min}$ and 1, 2, 3, 4, $5,6,21,22,23,24,26,27,29,30,45$ and $69 \mathrm{~h}$ after, DNA and total RNA were extracted from two $50 \mu \mathrm{L}$ samples. All DNA and RNA samples were analysed by mPCR and mRT-PCR.

\subsection{Construction of the PCR Internal Positive Control}

In order to check for PCR inhibitors, an Internal Positive Control (IPC) was constructed by PCR [21]. The primers CI-5 and CI-6 (Oligo Express) possessed 5' overlapping ends identical to the primers used in the $M$. synoviae PCR reaction, whereas their 3' ends were complementary to a $16 \mathrm{~S}$ rDNA sequence of $M$. synoviae (Tab. II). Thus the IPC was a 16S rDNA fragment of $645 \mathrm{bp}$ from $M$. synoviae generated by PCR. The PCR mixture contained the PCR buffer (67 mM Tris- $\mathrm{HCl}, 16 \mathrm{mM}\left(\mathrm{NH}_{4}\right)_{2} \mathrm{SO}_{4}$, $0.01 \%$ Tween $20,2.5 \mathrm{mM} \mathrm{MgCl}_{2}(\mathrm{pH} 8.8)$ ), a $500 \mu \mathrm{M}$ concentration of each dNTP (Pharmacia Biotech), $400 \mathrm{nM}$ of CI-5 and CI-6 primers, 1 unit of Taq DNA polymer- ase (Eurobio), and $5 \mu \mathrm{L}$ of a cell lysate of pure culture of $M$. synoviae WVU 1853 strain. Amplification was performed in a Perkin-Elmer Cetus GeneAmp PCR system 9600 (Perkin Elmer). The reaction procedure consisted of 40 cycles of denaturation at $94{ }^{\circ} \mathrm{C}$ for $30 \mathrm{~s}$, primer annealing at $65^{\circ} \mathrm{C}$ for $30 \mathrm{~s}$, and extension at $72{ }^{\circ} \mathrm{C}$ for $10 \mathrm{~s}$. The PCR product was purified using a commercially available kit (Life Technologies, Cergy Pontoise, France) and stored in doubledistilled water at $-20^{\circ} \mathrm{C}$. DNA concentration was determined spectrophotometrically.

\section{RESULTS}

\subsection{Specificity and sensitivity of the MPCR and sensitivity of the MRT-PCR}

The PCR assay enabled amplification of three fragments: the $645 \mathrm{bp}$ IPC, the $422 \mathrm{bp}$ fragment of the pcl42-56 gene of M. synoviae and the $270 \mathrm{bp}$ fragment of Mollicute $16 \mathrm{~S}$ rDNA gene. The three fragments were obtained with each of the $18 \mathrm{M}$. synoviae strains tested. The $M$. synoviae specific fragment was not obtained with any of the other species tested. The $270 \mathrm{bp}$ fragment was obtained only with the species belonging to Mycoplasma, Acholeplasma or Spiroplasma (but not Ureaplasma) genera. For all other genera tested (including Ureaplasma), only the band corresponding to the IPC was obtained.

mPCR and mRT-PCR were performed on serial dilutions of DNA and RNA extracts obtained from $M$. synoviae cultures. In our conditions, the detection limit of PCR was $1.65 \mathrm{CFU} /$ assay for the $M$. synoviae specific product and $0.165 \mathrm{CFU} /$ assay for the product shared between all species of Mycoplasma, Acholeplasma or Spiroplasma. The RT-PCR detection threshold was 6.6 CFU/assay for the M. synoviae protein specific product and $0.66 \mathrm{CFU} /$ assay for the Mollicutes 16S rRNA product. 


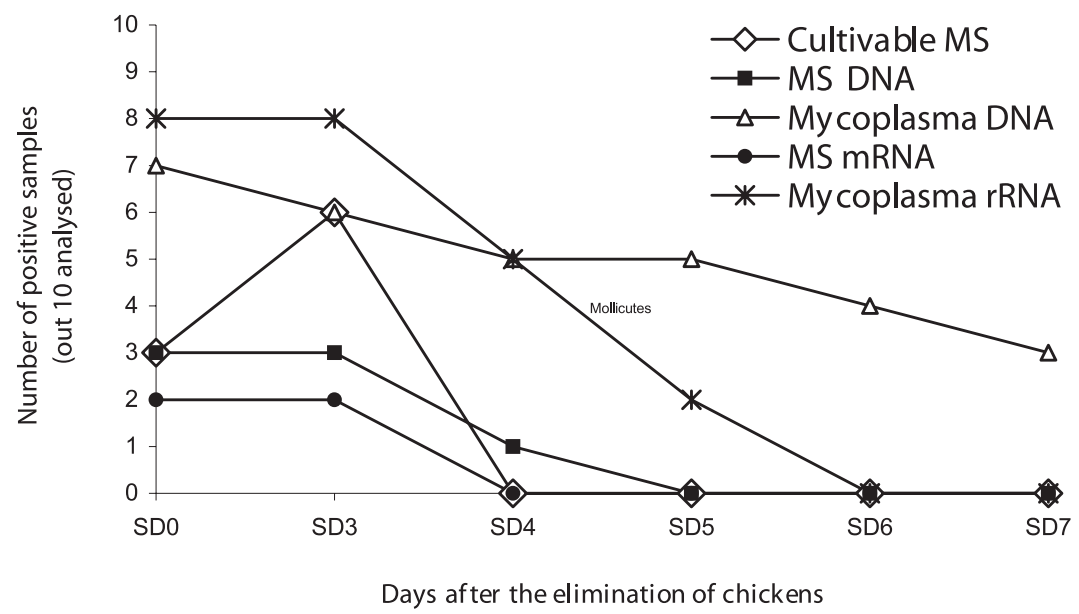

Figure 1. Detection of M. synoviae (MS) cultivable cells, DNA and mRNA and Mollicutes DNA and rRNA in the isolator environment after elimination of chickens infected during the first assay, as determined by culture, mPCR and mRT-PCR (experiment 2).

\subsection{Detection of mRNA and $16 \mathrm{~S}$ rRNA after mycoplasma death}

M. synoviae mRNA and $16 \mathrm{~S}$ rRNA could be detected up to $20 \mathrm{~min}$ and $23 \mathrm{~h}$ respectively after mycoplasma death. All samples collected up to $69 \mathrm{~h}$ (last sampling time) after mycoplasma death were positive by mPCR.

\subsection{Contamination experiments}

\subsubsection{Artificially contaminated isolator}

On D0, before isolator contamination, $M$. synoviae could not be detected by culture, mPCR and mRT-PCR in environmental samples. On D13, M. synoviae was detected in one chicken tracheal swab by culture and mPCR. On D27 and D34, all tracheal swabs analysed were positive by culture and mPCR. On D34, all chickens had $M$. synoviae specific antibodies according to the slide agglutination test (data not shown).

\subsubsection{Contamination of the isolator with experimentally infected chickens}

In the second experiment, $M$. synoviae could be isolated from only 3 feather samples on D0 and D3 and from 2 food samples on D3. M. synoviae DNA was detected on 3 water samples on D0, 1 feather and 2 water samples on D3 and 1 feather sample on D4. Mollicutes DNA was detected on all water samples from D0 to D7. Up to D5, most feather samples contained Mollicutes DNA whereas the only positive food sample was collected on D6. Drag-swab contained Mollicutes DNA only on D0. M. synoviae mRNA was detected only in one water sample and the drag-swab collected on D0, and in 2 feather samples on D3. Eight samples contained Mollicutes rRNA on D0 and on D3, and 5 (food, feather or water) and 2 (water) samples were positive on D4 and D5 respectively (Fig. 1). On D12, D18 and on D27 (6 days after avian infectious bronchitis virus inoculation), $M$. synoviae could not be detected by culture or by PCR on tracheal swabs. On D33 (12 days after virus 
inoculation), culture was positive for ten tracheas and ten air sacs, from a total of 14 infected birds. All 14 tracheas and 12 air sacs were positive according to $\mathrm{mPCR}$. Autopsy revealed that all chickens had severe airsacculitis lesions.

\subsubsection{Contamination of the isolator with naturally contaminated dust, feathers and food}

In the third experiment, on D0, before introduction of contaminated fomites, no $M$. synoviae could be detected by culture, mPCR and mRT-PCR in the isolator. Analysis of the fomites collected on the farm gave the following results; one food sample out of three enabled isolation of $M$. synoviae. Other samples were negative according to culture. Mollicutes DNA and rRNA could be amplified from six samples (1/3 food sample, and $5 / 6$ feather and dust mixes) but no $M$. synoviae specific product could be obtained. The many darkling beetles (Alphitobius diaperinus) present in these dust, feathers and food samples were destroyed after treatment with the disinfestant.

On D12, 26, 33, 40 and 47, according to culture, none of the 15 chicken tracheal swabs contained M. synoviae cells. However, on D12, and D26, mPCR detected Mollicutes DNA in one and two swabs, respectively. On D33, nine swabs contained M. synoviae DNA among which 5 contained Mollicutes DNA.

On D54, culture indicated that two chickens were colonised and $M$. synoviae and Mollicutes DNA fragments were detected on the same two tracheal swabs. On day 63 (6 days after inoculation of the IB virus), some birds exhibited tracheal rales and/or lameness. M. synoviae was isolated from seven tracheal swabs and all fifteen tracheal swabs were positive according to mPCR. On D69, according to culture and mPCR performed on tracheas, all the chickens were infected by $M$. synoviae. $M$. synoviae could also be detected from 12 air sacs and
12 spleens. Autopsy revealed that all chickens had severe airsacculitis lesions.

\section{DISCUSSION}

Three assays were performed to study $M$. synoviae environmental contamination of specific pathogen free chicks. In order to monitor the presence of $M$. synoviae or Mollicutes cells in environmental samples and in tracheal swabs, molecular tools were first developed.

The mPCR assay used in this study was based on the amplification of two gene fragments, one coding for a $M$. synoviae membrane protein (accession No. U66315) [2] and the other for Mollicutes 16S rRNA [23]. The results were specific for $M$. synoviae and Mycoplasma, Spiroplasma and Acholeplasma genera respectively. In fact, although the $M$. synoviae primers were selected in a gene coding for a membrane protein possibly subject to antigenic variations among $M$. synoviae isolates [19], amplification was positive for the 18 tested strains. Furthermore, the mPCR test contained an IPC to detect false negative results due to polymerase inhibitors and could be used, in most cases, directly on bacteria contaminated samples without DNA purification, except when the presence of inhibitors necessitated phenol-chloroform DNA extraction (data not shown).

The aim of the mRT-PCR was to enable the detection of viable $M$. synoviae in environmental samples $[1,5,11]$, because isolation of $M$. synoviae from such samples is made difficult by contaminating bacteria. The test, based on M. synoviae protein mRNA and Mollicutes 16S rRNA reversetranscription, was used directly on environmental samples after RNA extraction and purification. Stability of mRNA is limited [22] and its detection is correlated with the presence of metabolically active or very recently dead bacteria. Indeed, under our laboratory conditions, $M$. synoviae mRNA could be detected up to 20 min after mycoplasma death. The simultaneous detection 
of Mollicutes rRNA increased the sensitivity of the test and allowed the detection of Mycoplasma dead up to $23 \mathrm{~h}$ earlier. The difficulty of the assay was to maintain the samples in cold conditions and to begin the analysis within a very short time in order to keep viable mycoplasmas in environmental samples.

Environmental samples collected in the two isolators before the introduction of animals or contaminating materials did not contain Mollicutes 16S rRNA. Therefore, for the first and second assays, positive mPCR or mRT-PCR results with only the product shared by Mycoplasma, Acholeplasma and Spiroplasma genera were probably due to the presence of $M$. synoviae because the introduction into the isolator of Mollicutes other than M. synoviae was unlikely. On several occasions, the absence of the M. synoviae specific product could be due to higher sensitivities of mPCR or mRTPCR to detect Mycoplasma, Spiroplasma and Acholeplasma genera than $M$. synoviae species. This observation, coupled with the differences of targets for mRT-PCR, could also explain that Mollicutes DNA or rRNA could be detected longer than $M$. synoviae DNA or mRNA after elimination of infected chickens. Furthermore, the results also confirmed that mycoplasma DNA was much more stable than mycoplasma rRNA and that DNA detection was not predictive of the viability of bacterial pathogens [9].

Cultivable $M$. synoviae could be detected in the isolator after elimination of infected chickens, up to 3 days according to culture, in accord with the results of Christensen et al. [3] and viable cells were found up to 4-5 days as suggested by mRT-PCR.

The infectivity of the contaminated environment or fomites was clearly demonstrated as in each trial; the chicks, originating from SPF breeders, actually became $M$. synoviae infected. First positive tracheal swabs were obtained on day D13, D33 or D54. For the first and the third assay, only one and two positive birds were detected first respectively, then all other birds were $M$. synoviae culture positive, as usually observed under field conditions [12]. For the second and third assays, the delays between the introduction of birds in a contaminated environment and the detection of infection according to culture was surprisingly long ( 33 and 54 days respectively) compared to the delays before observation of clinical signs or lesions in the case of intra-tracheal (4 days) or aerosol inoculation (17-21 days) of SPF birds [12]. Such a long delay could probably result from a low infectious dose in fomites compared to relatively high titres of cultures used for challenge. Moreover such a long period before the development of mycoplasma clinical infection may be encountered in field conditions. Indeed according to Ley [14] M. gallisepticum flocks with a probable low level of infection, develop clinical infections near the onset of egg production in response to stressors. Similar $M$. synoviae extended incubation periods may also exist in the field. Problems associated with such a long latent infection are the determination of the origin of contamination and early detection of infection during this apparently silent period. It is emphasised that during the third trial, on D33, a few tracheal swabs gave a $M$. synoviae (but not Mollicutes) positive PCR result whereas the cultures were negative. The reason why only the species specific product was obtained in the absence of a Mollicute product is unknown. However the fact that on D12, D26 and D33, a few tracheal swabs yielded positive PCR signals might indicate that these birds had dead cells in their tracheas. Another possibility that needs further exploration is that birds could harbour viable but non cultivable cells. In fact different observations concerning samples from which no mycoplasma could be isolated but which were obviously infectious have been reported $[13,18]$ and in vivo bioassays are recommended when difficulties in isolating mycoplasmas are experienced [15]. This phenomenon seems reminiscent of the finding of Dallo and Baseman [4] which showed that intracellular M. genitalium could no longer be cultivated in artificial 
media. Indeed M. gallisepticum [27] and possibly also $M$. synoviae [26], have the capacity to enter eucaryotic cells and could be submitted to such biological alteration. Additional studies are necessary to explore this hypothesis.

Despite the lack of only IB inoculated controls, the results underlined the fact that the pathogenicity of $M$. synoviae seemed exacerbated when chickens were infected with avian infectious bronchitis virus, a rather common respiratory pathogen, since, according to the experience of the authors, infections due to $M$. synoviae alone or avian infectious bronchitis virus alone do not generate airsacculitis lesions. Finally, our results corroborate the observations of Hopkins and Yoder [8] showing that infectious bronchitis vaccine virus increases the $M$. synoviae capacity to induce airsacculitis in chickens.

In conclusion, the different assays showed that $M$. synoviae contaminated material (dust, feathers and food) can infect chicks, resulting in a delayed infection. Therefore, very strict hygiene rules must be respected by farmers and farm visitors and biosecurity measures (cleaning, disinfection and emptiness) must be rigorously applied. This study also demonstrated that the control of surface contamination by the use of mycoplasma culture or RT-PCR could be used to validate the efficiency of biosecurity measures before the introduction of new birds on the premises.

\section{ACKNOWLEDGEMENTS}

The authors thank Yannick Morin (AFSSAPloufragan) for skilled technical assistance, S.H. Kleven for providing M. synoviae strains, and Professor Y. Richard (National Veterinary School, Lyon, France) for helpful discussions.

\section{REFERENCES}

[1] Bej A.K., Mahbubani M.H., Atlas R.M., Detection of viable Legionella pneumophila in water by polymerase chain reaction and gene probe methods, Appl. Environ. Microbiol. 57 (1991) 597-600
[2] Ben Abdelmoumen B., Roy R.S., Brousseau R., Cloning of Mycoplasma synoviae genes encoding specific antigens and their use as species-specific DNA probes, J. Vet. Diagn. Invest. 11 (1999)162-169.

[3] Christensen N.H., Yavari C.A., McBain A.J., Bradbury J.M., Investigations into the survival of Mycoplasma gallisepticum, Mycoplasma synoviae and Mycoplasma iowae on materials found in the poultry house environment, Avian Pathol. 23 (1994) 127-143.

[4] Dallo S.F., Baseman J.B., Intracellular DNA replication and long-term survival of pathogenic mycoplasmas, Microb. Pathog. 29 (2000) 301-309.

[5] Del Mar Lleo M., Pierobon S., Tafi M.C., Signoretto C., Canepari P., mRNA detection by Reverse Transcription-PCR for monitoring viability over time in an Enterococcusfaecalis viable but nonculturable population maintained in a laboratory microcosm, Appl. Environ. Microbiol. 66 (2000) 4564-4567.

[6] Frey M.L., Hanson R.P., Anderson D.P., A medium for isolation of avian mycoplasmas, Am. J. Vet. Res. 29 (1968) 2163-2171.

[7] Hopkins S.R., Serological comparisons of strains of infectious bronchitis virus using plaque-purified isolants, Avian Dis. 18 (1974) 231-239.

[8] Hopkins S.R., Yoder H.W.J., Reversion to virulence of chicken-passaged infectious bronchitis vaccine virus, Avian Dis. 30 (1986) 221-223.

[9] Josephson K.L., Gerba C.P., Pepper I.L., Polymerase Chain Reaction detection of nonviable bacterial pathogens, Appl. Environ. Microbiol. 59 (1993) 3513-3515.

[10] Kellog D.E., Kwok S., Detection of human immunodefidiency virus, in: Innis M.A., Gelfand D.H., Sninsky J.J., White T.J. (Eds.), PCR protocols: a guide to methods and amplification, Academic Press, San Diego, 1990, pp. 339-343.

[11] Klein P.G., Juneja V.K., Sensitive detection of viable Listeria monocytogenes by reverse transcription-PCR, Appl. Environ. Microbiol. 63 (1997) 4441-4448.

[12] Kleven S.H., Mycoplasma synoviae infection, in: Saif Y.M., Barnes H.J., Glisson J.R., Fadly A.M., McDougald L.R., Swayne D.E. (Eds.), Diseases of Poultry, 11th ed., Iowa State Press, Ames, Iowa, 2003, pp. 756-771.

[13] Levisohn S., Kleven S.H., Avian mycoplasmosis (Mycoplasma gallisepticum), Rev. Sci. Tech. 19 (2000) 425-42.

[14] Ley D.H., Mycoplasma gallisepticum infection, in: Saif Y.M., Barnes H.J., Glisson J.R., 
Fadly A.M., McDougald L.R., Swayne D.E. (Eds.), Diseases of Poultry, 11th ed., Iowa State Press, Ames, Iowa, 2003, pp. 722-744.

[15] Mallinson E.T., Eckroade R.J., Kleven S.H., In vivo bioassay and supplemental serologic techniques for the detection of Mycoplasma in suspect breeding chickens, Avian Dis. 25 (1981) 1077-1082.

[16] Marois C., Dufour-Gesbert F. Kempf I., Detection of Mycoplasma synoviae in poultry environment samples by culture and polymerase chain reaction, Vet. Microbiol. 73 (2000) 311-318.

[17] Marois C., Savoye C., Kobisch M., Kempf I., A reverse-transcription PCR assay to detect viable Mycoplasma synoviae in environmental samples, Vet. Microbiol. 89 (2002) 17-28.

[18] McMartin D.A., Persistence of Mycoplasma gallisepticum infection, Vet. Rec. 81 (1967) 387.

[19] Noormohammadi A.H., Markham P.F., Whithear K.G., Walker I.D., Gurevich V.A., Ley D.H., Browning G.F., Mycoplasma synoviae has two distinct phase-variable major membrane antigens, one of which is a putative hemagglutinin, Infect. Immun. 65 (1997) 2542-2547.

[20] Rodwell A.W., Whitcomb R.F., Methods for direct and indirect measurement of mycoplasma growth, in: Razin S., Tully J.G. (Eds.), Methods in Mycoplasmology, Vol. 1, Academic Press, New York, USA, 1983, pp. 185 196.

[21] Sachadyn P., Kur J., The construction and use of a PCR internal control, Mol. Cell. Probes 12 (1998) 259-262.
[22] Sheridan G.E.C., Masters C.I., Shallcross J.A., Mackey B.M., Detection of mRNA by Reverse Transcription-PCR as an indicator of viability in Escherichia coli cells, Appl. Environ. Microbiol. 64 (1998) 1313-1318.

[23] Van Kuppeveld F.J., van der Logt J.T., Angulo A.F., van Zoest M.J., Quint W.G., Niesters H.G., Galama J.M., Melchers W.J., Genus and species-specific identification of mycoplasmas by 16S RNA amplification, Appl. Environ. Microbiol. 58 (1992) 2606-2615.

[24] Van Kuppeveld F.J., van der Logt J.T., Angulo A.F., van Zoest M.J., Quint W.G., Niesters H.G., Galama J.M., Melchers W.J., Author's correction: Genus and species-specific identification of mycoplasmas by 16S RNA amplification, Appl. Environ. Microbiol. 59 (1993) 655.

[25] Villegas P., Purchase H.G., Titrations of biological suspensions, in: Purchase H.G., Arp L.H., Domermuth C.H,. Pearson J.E. (Eds.), A laboratory manual for the isolation and identification of avian pathogens, 3rd ed., Kendall/ Hunt Publishing co., Dubuque, USA, 1989, pp.186-190.

[26] Walker E.R., Friedman F.H., Olson N.O., Sahu S.P., Mengoli H.F., An ultrasutructural study of avian synovium infected with an arthrotropic mycoplasma, Mycoplasma synoviae, Vet. Pathol. 15 (1978) 407-416.

[27] Winner F., Rosengarten R., Citti C., In vitro cell invasion of Mycoplasma gallisepticum, Infect. Immun. 68 (2000) 4238-4244. 